\title{
SCREENING OF SOME CULTIVATED HYBRIDS OF MAIZE (Zea mays L.) FOR PRODUCTIVITY IN THE JOS-PLATEAU ENVIRONMENT
}

\author{
O. A. T. NAMO AND E. D. KYENPIYA
}

(Received 18, January 2012; Revision Accepted 20, February 2012)

\begin{abstract}
Two experiments were carried out at the Research Farm of the National Root Crops Research Institute, Kuru near Jos, during the 2007 and 2008 planting seasons, to study the productivity of seven (7) hybrid varieties of maize (Zea maysL.), namely SUWAN-1-Y, 'Kenya Kitali', ACR-9776-2, TZMSR-W, DMESR-Y, ACROSS-98 and TZPBSR-W. The experiments were laid out in a randomized complete block design (RCBD) with three replications. The results show that the germination rate was similar across the varieties in 2007; it was higher in the variety ACR-9776-2 $(91.67 \%)$ than in the variety DMESR-Y $(79.58 \%)$ in 2008 . The highest mean number of days to mid-tasselling in 2007 (76.50) and 2008 (81.17) as well as the mid-silking in 2007(88.33) and 2008 (95.33) were observed in the variety 'Kenya Kitali'. Similarly, the highest mean plant height in $2007(2.07 \mathrm{~m})$ and $2008(2.07 \mathrm{~m})$ as well as the mean earwidth in $2007(16.96 \mathrm{~cm})$ were observed in the variety 'Kenya Kitali'. The variety also had the highest one-thousand seed weight in $2007(377.90 \mathrm{~g})$ and $2008(456.71 \mathrm{~g})$. The variety ACR-9776-2 out-yielded the other varieties in the mean number of kernels per row in 2007 (21.79) and 2008 (29.60). The variety also had the highest shelling percentage in $2007(88.77 \%)$ and $2008(78.45 \%)$. The highest mean number of rows per ear was observed in the variety DMESR-Y in 2007 (15.97) and in the pooled data (14.47). In both years the varieties did not differ significantly in the mean ear-weight, although this was generally higher in 2007 than in 2008 . The grain yield per plant was highest in the variety ACROSS-98 (139.93 g plant $^{-1}$ ) in 2007 but in 2008 it was similar across the varieties. Total grain yield in 2007 was significantly higher in the variety ACROSS-98 $\left(4.37 \mathrm{t} \mathrm{ha}^{-1}\right)$ than in the other varieties. Grain yield was similar across the varieties in 2008 and in the pooled results. Generally, grain yield and its components were higher in 2007 than in 2008. The study shows that growth, grain yield and yield components of maize vary with variety and environment and that the varieties ACROSS-98, ACR-9776-2, TZMSR-W and 'Kenya Kitali' have potentials for high productivity in the Jos-Plateau environment.
\end{abstract}

KEY WORDS: Productivity, Zea Mays, Environment.

\section{INTRODUCTION}

Maize (Zea maysL.)is an important cereal crop of the world. It is used as human and animal food and as a raw material for the manufacture of hundreds of industrial products including corn starch, maltodextrins, corn syrup and products of fermentation and distillation industries.

It is grown from $58^{\circ} \mathrm{N}$ to $40^{\circ} \mathrm{S}$, from below sea level to latitudes higher than 3,000 metres and in areas with $250 \mathrm{~mm}$ to more than $5,000 \mathrm{~mm}$ of rainfall per annum (Shaw 1988; Downswell et al., 1996). Most of the crop is grown in the warmer parts of the temperate regions and in the humid sub-tropical climate. The greatest production is in areas having the warmest isotherms from $21^{\circ}$ to $27^{\circ} \mathrm{C}$ and a frost-free season of 120-to 180-day duration. The major maize-growing countries include the U.S.A., China, Mexico, Brazil, Argentina, India, Indonesia, the Philippines and Thailand (USDA, 1996). Worldwide, maize production continues to increase but at a slower rate than in the earlier years. The demand in 2020 is estimated to reach about 138 percent of the demand in 1995 (Rosegrant et al., 1995; USDA, 1996). Presently, the industrialized world uses more maize than the developing world, but forecasts indicate that by 2020 developing countries will demand more maize than the industrialized world (Duvick, 1998).
The projected increase will certainly not be large enough to satisfy the projected demand. Increasing emphasis must, therefore, be placed on significantly enhancing productivity per unit area, particularly in the maize growing countries in the developing world, where the average maize productivity is $2.4 \mathrm{t} \mathrm{ha}^{-1}$ compared to $5.9 \mathrm{t} \mathrm{ha}^{-1}$ in the developed world (CIMMYT, 1994).

The grain yield of maize is the most important and complex trait. It is quantitatively inherited and its expression is influenced by several yield components, including number of ears, kernel rows, kernels per row, test weight and shelling percentage. The important physiological traits influencing grain yield include nutrient uptake, photosynthesis, translocation, sink-size, transpiration and respiration. Grain yield also depends on maturity duration, standability and resistance to abiotic stresses (Dhillon and Prassanna, 2001).

Cultivated varieties may be open-pollinated (OP) population or hybrid between inbred lines. Hybrid cultivars have the advantage of higher yield potential and uniformity. They are, therefore, preferred to openpollinated populations when there is sufficient heterosis. But the production of hybrid seed is costlier and complicated. For this reason and in order to meet the increasing demands as well as to maximize profit, there is a tendency for local seed-producing companies to

O. A. T. Namo, Department of Plant Science and Technology University of Jos P.M.B. 2084, Jos, Plateau State, Nigeria

E. D. Kyenpiya, Department of Plant Science and Technology University of Jos P.M.B. 2084, Jos, Plateau State, Nigeria 
compromise standards. Therein lies the need to continually screen cultivated varieties to ascertain their yield potentialities. The present study was, therefore, designed to screen seven (7) hybrids of maize for their productivity in the Jos-Plateau environment.

\section{MATERIALS AND METHODS}

Experimental Location: The experiments were carried out during the wet seasonsof 2007 and 2008 at the Research Farm of the National Root Crops Research Institute (NRCRI), located at Kuru, near Jos, in NorthCentral Nigeria.Jos lies within latitude $09^{\circ} 44^{\prime} \mathrm{N}$ andlongitude $08^{\circ} 47^{\prime} \mathrm{E}$ and atan altitude of $1,293.2 \mathrm{~m}$ above sea-level. The total annual rainfall in 2007 and 2008 was $970 \mathrm{~mm}$ and $1.070 \mathrm{~mm}$, respectively. The mean relative humidity was $50 \%$ in 2007 and $46 \%$ in 2008. The mean maximum and minimum temperatures were $27^{\circ} \mathrm{C}$ and $17^{\circ} \mathrm{C}$, respectively, in 2007 . In the year 2008 the maximum temperature was $26^{\circ} \mathrm{C}$ while the minimum was $17^{\circ} \mathrm{C}$.

Land Preparation: Landpreparation,including ploughing and ridging, was done using a tractor. During each year's planting, the gross plot size was $44.8 \mathrm{~m} \times 13 \mathrm{~m}$. Each net plot measuring $4 \mathrm{~m} \times 3.2 \mathrm{~m}$, consisted of four rows, each measuring $4 \mathrm{~m}$ long and $0.8 \mathrm{~m}$ wide.

Planting: Six of the seven varieties (SUWAN-1-Y, ACR9776-2, TZMSR-Y, DMESR-Y, ACROSS-98 and TZPBSR-W) used in the study were obtained from the National Seed Service Centre of the Federal Department of Agriculture, Bukuru, Plateau State, while the seventh variety ('Kenya Kitali') was obtained from a research scientist in Kenya. The experiment was laid out in a randomized complete block design with three replications.

Before planting on May 24, 2007 and May 31, 2008, the seeds were treated with Apron Plus ${ }^{\circledR}$ to prevent attack by soil-borne pathogens. A sachet of the powdered chemical was poured on the seeds (about 2 $\mathrm{kg}$ of each variety) in a container and shaken to ensure thorough mixing. Two seeds per hill were sown at a spacing of $0.4 \mathrm{~m}$ (within row) and $0.8 \mathrm{~m}$ (between row). Seedlings were thinned down to one per hill at 23 days after planting to give a plant population of 31,250 plants $\mathrm{ha}^{-1}$ each year.

Cultural Practice: At 16 days after planting (16 DAP), compound fertilizer, NPK (15-15-15) was applied to all plots at the rate of $150 \mathrm{~kg} \mathrm{ha}^{-1}$, which was equivalent to $320 \mathrm{~g}$ per plot. A basal application of $\mathrm{N}$-fertilizer (urea) was supplied at the rate of $50 \mathrm{~kg} \mathrm{ha}^{-1}$ or $83.6 \mathrm{~g}$ per plot at 65 DAP in 2007 and 70 DAP in 2008 in order to supplement the loss due to leakages caused by excessive rainfall.
The plots were hoe-weeded twice at 32 DAP and 89 DAP in both 2007 and 2008. In between the two weedings, the plots were earthed up at 58 DAP in the two years to prevent lodging.

\section{FIELD OBSERVATIONS AND DATA COLLECTION}

\section{Germination Rate}

This was computed as the ratio of the number of seeds that germinated ten days after sowing to the total number of seeds planted and multiplied by 100 .

\section{Mean Number of Days to Mid-Tasselling}

This was recorded as the number of days from planting to when at least $50 \%$ of the total number of pants in each plot had tasseled.

\section{Mean Number of Days to Mid-Silking}

This was recorded as the number of days from planting to when at least $50 \%$ of the total number of plants in each plot had silked.

\section{Plant Height at Harvest}

Five (5) plants were sampled from each plot each of which was measured from the ground level to the flag leaf.

\section{Mean Number of Ears per Plant}

The total number of ears harvested from each plot was divided by the number of plant stands in the respective plots at harvest to obtain the mean number of ears per plant.

\section{Mean Ear-Length}

Five (5) ears were sampled from each plot, each of which was measured from the bottom to the top. The mean was used for the statistical analysis.

\section{Mean Ear-Width}

Each of the five (5) sampled ears was measured at the widest portion and the mean was used for the statistical analysis.

\section{Mean Number of Rows per Ear}

From each of the five (5) sampled ears, the number of rows was counted and divided by five to obtain the mean number of rows per ear. 


\section{Mean Number of Kernels per Row}

From each of the five (5) sampled ears, the kernels of three rows were counted and recorded. The mean was used for the statistical analysis.

\section{Mean Ear-Weight}

After sun-drying the ears harvested in each plot for seven (7) days, five (5) of them were sampled and weighed. The weight obtained was divided by five (5) to give the mean ear-weight.

\section{Shelling Percentage}

Each of the five (5) ears sampled was weighed with the kernels. Thereafter, the ear was shelled and the kernels alone were weighed. Shelling percentage was computed as the ratio of the weight of the kernels to the weight of the kernels plus the cob and multiplied by 100 as follows:

$$
\text { Shelling percentage } \%=\underline{b} \times 100
$$

where, $a=$ weight of kernels $+c o b$

$b=$ weight of kernels alone

\section{One Thousand Seed Weight}

From the whole grain-lot harvested from each plot, one thousand $(1,000)$ seeds were taken and weighed.

\section{Grain Yield per Plant}

The grain shelled from five (5) cobs harvested from five (5) sampled plants in each plot was weighed and divided by five (5) to obtain the grain yield per plant.

\section{Total Grain Yield}

The cobs harvested from each plot were sundried, shelled and weighed. Total grain yield was computed at $12 \%$ moisture, which is the safe storage moisture level.

\section{Data Analysis}

Data collected from the two-year experiment were analysed separately and then pooled, using the one-way analysis of variance (ANOVA) test. Means were compared using the Duncan's new Multiple-Range Test (DMRT) (Steel and Torrie, 1960).

\section{RESULTS}

\section{Germination Rate}

The results of the germination rate for 2007 and 2008 planting seasons are presented in Table 1. The results showed that the germination rate was $100 \%$ in the varieties 'Kenya Kitali', TZMSR-W and DMESR-Y in 2007. In 2008, the germination rate in the varieties 'Kenya Kitali', TZMSR-W and DMESR-Ywas 83.75\%, $85.42 \%$ and $79.58 \%$, respectively. In 2007 , the germination rate was $99.17 \%$ in the varieties SUWAN-1$Y$ and TZPBSR-W, 99.19\% in ACR-9776-2 and 99.58\% in ACROSS-98. In 2008, the germination rates in SUWAN-1.Y, TZPBSR-W, ACR-9776-2 and ACROSS98 were $83.33 \%, 87.50 \%$ and $91.67 \%$, respectively. In the 2007 planting season, the varieties did not differ significantly in germination rate; in 2008 , the variety ACR-9776-2 recorded a significantly higher germination rate $(91.07 \%)$ than the variety DMESR-Y $(79.58 \%)$.

\section{Mean Number of Days to mid-Tasselling}

In 2007, the mean number of days to midtasselling varied from 72.00 in the variety ACROSS-98 to $72.33,73.00,73.67,75.00$ and 76.50 days in the varieties TZMSR-W, SUWAN-1-Y, ACR-9776-2, TZPBSR-W and DMESR-Y, respectively. In 2008, the mean number of days to mid-tasselling was 80.50 , $81.17,78.83,82.67,78.83,79.33$ and 77.67 in the varieties SUWAN-1-Y, 'Kenya Kitali', ACR-9776-2, TZMSR-W, DMESR-Y, ACROSS-98 and TZPBSR-W, respectively. The mean number of days to mid-tasselling in the variety 'Kenya Kitali' was higher than in the other varieties. In the year 2008, the number of days to midtasselling did not differ significantly amongst the varieties. The number of days to mid-tasselling was generally higher in 2008 than in 2007 (Table 1).

\section{Mean Number of Days to Mid-Silking}

Table 1 shows the results of the number of days to mid-silking in 2007 and 2008. The variety 'Kenya Kitali' had the highest number of days to mid-silking in 2007 (88.33). This was followed by the varieties TZPBSR-W (82.83 days), ACR-9776-2 (81.67 days), SUWAN-1-Y (78.00 days) and DMESR-Y (77.83 days). In 2008, the mean number of days to mid-silking varied from 83.33 in the variety SUWAN-1-Y to 95.33 in the variety 'Kenya Kitali'. Again the number of days to midsilking was generally higher in 2008 than in 2007.

\section{Plant Height}

The results of the effect of variety on plant height of maize in 2007 and 2008 are shown in Table 2. The highest plant height of $2.07 \mathrm{~m}$ in 2007 was observed in the variety 'Kenya Kitali', and this was followed by the varieties TZPBSR-W $(1.88 \mathrm{~m})$, TZMSRW (1.82 m), ACROSS-98 (1.65 m), SUWAN-1-Y (1.59 $\mathrm{m})$, ACR-9776-2 $(1.58 \mathrm{~m})$ and DMESR-Y $(1.58 \mathrm{~m})$. The variety 'Kenya Kitali' also had the highest plant height of 2.07 metres in 2008, and was followed by the varieties TZPBSR-W (1.94 m), ACR-9776.2 (1.76 m), TZMSR-W $(1.76 \mathrm{~m})$, ACROSS-98 (1.72 m) and SUWAN-1-Y (1.55 $\mathrm{m})$.

\section{Mean Number of Ears per Plant}

The results of the mean number of ears per plant are shown in Table 2. In the year 2007, the mean number of ears per plant ranged from 1.06 in the varieties, SUWAN-1.Y, ACR-9776-2, TZMSR-W and DMESR-Y to 1.03 in the varieties 'Kenya Kitali' and ACROSS-98. Differences amongst the varieties were, however, not significant. In 2008, the highest number of ears per plant (1.07) was observed in the variety TZPBSR-W, followed by the varieties ACROSS-98 (1.05), ACR-9776-2(0.93), SUWAN-1-Y (0.92), TZMSRW (0.90) and DMESR-Y (0.82). The mean number of ears per plot was generally lower in 2008 than in 2007.

\section{Mean Ear-Length}

Table 2 shows the results of the ear-length in 2007 and 2008. In 2007 the ear-length in the variety TZMSR-W $(17.25 \mathrm{~cm})$ was the highest, followed by the varieties ACR-9776-2 $(17.04 \mathrm{~cm})$, ACROSS-98 (17.01 $\mathrm{cm})$, 'Kenya Kitali' $(16.36 \mathrm{~cm})$, SUWAN-1-Y $(16.27 \mathrm{~cm})$ and TZPBSR-W $(15.79 \mathrm{~cm})$. In 2008, the mean earlength ranged from $13.93 \mathrm{~cm}$ in the variety TZMSR-W to 
$10.11 \mathrm{~cm}$ in ACR-9776-2. The mean ear-length was generally higher in 2007 than in 2008.

\section{Mean Ear-Width}

The results of the mean ear-width in the twoyear experiment are shown in Table 2. The highest mean ear-width in 2007 was observed in the variety 'Kenya Kitali' $(16.96 \mathrm{~cm})$ and was followed by the varieties SUWAN-1-Y (16.82 cm), ACROSS-98(16.17 $\mathrm{cm})$, TZMSR-W $(15.76 \mathrm{~cm})$ and TZPBSR-W $(15.61 \mathrm{~cm})$. In 2008 the ear-width in the seven varieties studied were statistically similar, ranging from $14.71 \mathrm{~cm}$ in the variety TZMSR-W to $13.70 \mathrm{~cm}$ in the variety 'Kenya Kitali'. Again, ear length was generally higher in 2007 than in 2008.

\section{Mean Number of Rows per Ear}

The mean number of rows per ear was highest in the variety DMESR-Y (15.97) and lowest in the variety 'Kenya Kitali' (11.23) in 2007. The mean number of rows per ear did not differ significantly $(p=0.05)$ amongst the other varieties. In the year 2008,the mean number of rows per ear was statistically similar across the varieties. Generally, the mean number of rows per ear was higher in 2007 than in 2008 in all the varieties except 'Kenya Kitali' (Table 3).

\section{Mean Number of Kernels per Row}

The results of the mean number of kernels per row in 2007 and 2008 are shown in Table 3. In 2007 the highest mean number of kernels per row (37.41) was observed in the variety ACR-9776-2 and this was followed by the varieties ACROSS-98 (34.30), DMESRY (33.90), TZMSR-W (33.27), TZPBSR-W (32.13), SUWAN-1-Y (31.04) and 'Kenya Kitali'(28.04). In 2008, the mean number of kernels per row was $21.79,21.42$, $20.08,19.38,18.92,18.81$ and 18.13 in the varieties ACR-9776-2, TZMSR-W, TZPBSR-W, 'Kenya Kitali', ACROSS-98, SUWAN-1-Y and DMESR-Y, respectively. The mean number of kernels per row did not differ significantly amongst the varieties. In all the varieties, the mean number of kernels per row was higher in 2007 than in 2008.

\section{Mean Ear-Weight}

Table 3 shows the mean ear-weight in the two years of experimentation. The mean ear-weight was $171.98 \mathrm{~g}$ in the variety ACROSS-98 and $136.87 \mathrm{~g}$ in the variety TZPBSR-W in 2007. The varieties TZMSR-W, SUWAN1-Y, DMESR-Y, ACR-9776-2 and 'Kenya Kitali' had the mean ear-weights of $165.95,152.87,148.91,144.56$ and $141.22 \mathrm{~g}$, respectively. In the year 2008, the highest mean ear-weight $(112.80 \mathrm{~g})$ was observed in the variety TZPBSR-W. This was followed by the varieties 'Kenya Kitali' (101.71 g), ACR-9776-2 (93.03 g), TZMSR-W (92.52 g), ACROSS-98 (89.81 g), SUWAN-1-Y (87.30 g) and DMESR-Y $(82.09 \mathrm{~g})$. In both years the mean earweight did not differ significantly amongst the varieties.

\section{Shelling Percentage}

The result of the shelling percentage in the seven varieties of maize studied in 2007 and 2008 is presented in Table 3. In 2007, the varieties ACR-9776-2 and 'Kenya Kitali' had the highest and the lowest shelling percentage of 88.77 and $78.78 \%$, respectively. The shelling percentage in the varieties ACR-9776-2 (81.51\%), TZMSR-W (81.58\%) and TZPBSR-W $(81.13 \%)$ did not differ significantly $(p=0.05)$. In 2008 , the highest shelling percentage was observed in the variety ACR-9776-2 (78.45\%) while the lowest was observed in the variety 'Kenya Kitali' $(64.76 \%)$. Shelling percentage was $77.61,76.44,75.22,73.98$ and $69.02 \%$ in the varieties TZPBSR-W, SUWAN-1-Y, TZMSR-W, DMESR-Y and ACROSS-98, respectively. In all the varieties, shelling percentage was higher in 2007 than 2008.

\section{One Thousand Seed Weight}

The result of the one thousand seed weight is shown in Table 4. In 2007, the variety 'Kenya Kitali' had the highest 1,000-seed weight of $377.90 \mathrm{~g}$, followed by the varieties TZMSR-W (290.22 g), ACROSS-98 (285.41 g), SUWAN-1-Y (252.96 g), TZPBSR-W (246.79 g), DMESR-Y (235.88 g) and ACR-9776-2 (227.46 g). In 2008, the highest and the lowest one thousand-seed weights of $456.71 \mathrm{~g}$ and $256.74 \mathrm{~g}$ were also observed in the varieties 'Kenya Kitali' and ACR-9776-2, respectively. The one-thousand seed weights in the varieties ACROSS-98, SUWAN-1-Y, TZPBSR-W, TZMSR-W and DMESR-Y were 318.14, 287.22, 287.00, 266.25 and $265.91 \mathrm{~g}$, respectively. Besides the variety TZMSR-W, the 1,000 seed-weight in all the varieties was higher in 2008 than in 2007.

\section{Grain Yield per plant}

Results of the grain yield per plant in 2007 and 2008 are shown in Table 4. The highest grain yield per plant of $139.93 \mathrm{~g}$ in 2007 was observed in the variety ACROSS-98 and this was followed by the varieties TZMSR-W (135.83 g), SUWAN-1-Y (126.75 g), ACR9776-2 (116.97 g), TZPBSR-W (113.53 g), 'Kenya Kitali' $(110.58 \mathrm{~g})$ and DMESR-Y $(108.99 \mathrm{~g})$. In 2008, the grain yield per plant was 89.56, 75.71, 72.04, 69.78, 68.52, 65.17 and $61.86 \mathrm{~g}$ in the varieties TZPBSR-W, ACR9776-2,'Kenya Kitali', TZMSR-W, SUWAN-1-Y, ACROSS-98 and DMESR-Y, respectively. The varieties did not differ significantly in the grain yield per plant in 2008. The grain yield per plant was generally higher in 2007 than in 2008 in all the varieties studied.

\section{Total Grain Yield}

Table 4 shows results of the total grain yield of seven varieties of maize in 2007 and 2008. In the year 2007 , the highest total grain yield of $4.37 \mathrm{t} \mathrm{ha}^{-1}$ was observed in the variety ACROSS-98, followed closely by varieties TZMSR-W, SUWAN-1-Y, ACR-9776-2 and TZPBSR-W with total grain yields of $4.25,3.96,3.66$ and $3.55 \mathrm{t} \mathrm{ha}^{-1}$. The lowest total grain yield of $3.40 \mathrm{tha}^{-1}$ was observed in the variety DMESR-Y. In 2008 the total grain yield varied from $2.80 \mathrm{t} \mathrm{ha}^{-1}$ in the variety TZPBSR$\mathrm{W}$ to $2.37,2.25,2.18,2.14,2.04$ and $1.94 \mathrm{t} \mathrm{ha}^{-1}$ in the varieties ACR-9776-2, 'Kenya Kitali', TZMSR-W, SUWAN-1-Y, ACROSS-98 and DMESR-Y, respectively. The differences were, however, not significant. Across the varieties, the total grain yield was higher in 2007 than in 2008. 
Table 1: Effect of Variety on germination rate, days to mid-tasselling, days to mid-silking and stand count at harvest in maize in Jos-Plateau.

\begin{tabular}{|c|c|c|c|c|c|c|c|c|c|}
\hline \multirow{2}{*}{$\begin{array}{l}\text { Treatment: } \\
\text { Variety }\end{array}$} & \multicolumn{3}{|c|}{ Germination Rate } & \multicolumn{3}{|c|}{ Days to Mid-tasselling } & \multicolumn{2}{|c|}{ Days to Mid-Silking } & \multirow[b]{2}{*}{ Pooled } \\
\hline & 2007 & 2008 & Pooled & 2007 & 2008 & Pooled & 2007 & 2008 & \\
\hline SUWAN-I-Y & $99.17^{\mathrm{a}}$ & $83.33^{\mathrm{bc}}$ & $91.25^{\mathrm{a}}$ & $73.00^{c}$ & $80.50^{a}$ & $76.75^{\mathrm{a}}$ & $78.00^{c}$ & $83.33^{\mathrm{C}}$ & $80.67^{b}$ \\
\hline KENYA KITALI & $100.00^{\mathrm{a}}$ & $83.75^{\mathrm{bc}}$ & $91.88^{\mathrm{a}}$ & $76.50^{\mathrm{a}}$ & $81.17^{\mathrm{a}}$ & $78.83^{\mathrm{a}}$ & $88.33^{\mathrm{a}}$ & $95.33^{\mathrm{a}}$ & $91.84^{\mathrm{a}}$ \\
\hline ACR-9776-2 & $99.19^{\mathrm{a}}$ & $91.67^{\mathrm{a}}$ & $95.63^{a}$ & $73.67^{\mathrm{bc}}$ & $78.83^{\mathrm{a}}$ & $76.25^{a}$ & $81.67^{b}$ & $86.67^{\mathrm{bc}}$ & $84.17^{\mathrm{b}}$ \\
\hline TZMSR-W & $100.00^{\mathrm{a}}$ & $85.42^{b}$ & $92.71^{a}$ & $72.33^{\mathrm{c}}$ & $82.67^{\mathrm{a}}$ & $77.50^{\mathrm{a}}$ & $77.33^{c}$ & $88.00^{\mathrm{b}}$ & $82.67^{b}$ \\
\hline DMESR-Y & $100.00^{\mathrm{a}}$ & $79.58^{\mathrm{C}}$ & $89.79^{a}$ & $73.67^{\mathrm{bc}}$ & $78.83^{\mathrm{a}}$ & $76.26^{a}$ & $77.83^{\mathrm{C}}$ & $84.83^{\mathrm{bc}}$ & $81.33^{b}$ \\
\hline ACROSS-98 & $99.58^{\mathrm{a}}$ & $87.08^{\mathrm{b}}$ & $93.34^{a}$ & $72.00^{\mathrm{c}}$ & $79.33^{a}$ & $75.67^{\mathrm{a}}$ & $77.50^{c}$ & $86.17^{\mathrm{bc}}$ & $81.83^{b}$ \\
\hline TZPBSR-W & $99.17^{\mathrm{a}}$ & $87.50^{\mathrm{ab}}$ & $93.33^{\mathrm{a}}$ & $75.00^{\mathrm{ab}}$ & $77.67^{\mathrm{a}}$ & $76.17^{\mathrm{a}}$ & $82.83^{b}$ & $85.83^{b c}$ & $84.34^{b}$ \\
\hline CV (\%) & 0.85 & 4.12 & 4.44 & 1.93 & 6.32 & 2.90 & 2.45 & 3.85 & 3.38 \\
\hline
\end{tabular}

Table 2: Effect of Variety on plant height, mean number of ears per plant, mean ear-length and mean-ear-width of maize in Jos-Plateau.

\begin{tabular}{|c|c|c|c|c|c|c|c|c|c|c|c|c|}
\hline \multirow{2}{*}{$\begin{array}{l}\text { Treatment: } \\
\text { Variety }\end{array}$} & \multicolumn{3}{|c|}{ Plant height (m) } & \multicolumn{2}{|l|}{ Ear No/plant } & \multicolumn{3}{|c|}{ Mean ear-length $(\mathrm{cm})$} & \multicolumn{3}{|c|}{ Mean ear-width $(\mathrm{cm})$} & \multirow[b]{2}{*}{ Pooled } \\
\hline & 2007 & 2008 & Pooled & 2007 & 2008 & Pooled & 2007 & 2008 & Pooled & 2007 & 08 & \\
\hline SUWAN-I-Y & $1.59^{\mathrm{C}}$ & $1.55^{\mathrm{c}}$ & $1.57^{\mathrm{d}}$ & $1.06^{a}$ & $0.92^{\mathrm{abc}}$ & $0.99^{\mathrm{a}}$ & $16.27^{\mathrm{ab}}$ & $12.62^{\mathrm{ab}}$ & $14.94^{\mathrm{ab}}$ & $16.82^{a b}$ & $14.25^{\mathrm{a}}$ & $15.54^{\mathrm{a}}$ \\
\hline KENYA KITALI & $2.07^{\mathrm{a}}$ & $2.07^{\mathrm{a}}$ & $2.07^{\mathrm{a}}$ & $1.03^{\mathrm{a}}$ & $0.77^{\mathrm{C}}$ & $0.90^{\mathrm{a}}$ & $16.36^{\mathrm{ab}}$ & $12.14^{\mathrm{ab}}$ & $14.40^{\mathrm{ab}}$ & $16.96^{\mathrm{a}}$ & $13.70^{\mathrm{a}}$ & $15.33^{\mathrm{a}}$ \\
\hline ACR-9776-2 & $1.58^{\mathrm{C}}$ & $1.76^{\mathrm{bc}}$ & $1.67^{\mathrm{cd}}$ & $1.06^{\mathrm{a}}$ & $0.93^{\mathrm{abc}}$ & $1.00^{a}$ & $17.04^{\mathrm{a}}$ & $10.11^{b}$ & $13.57^{b}$ & $15.00^{\text {cd }}$ & $14.59^{a}$ & $14.79^{\mathrm{a}}$ \\
\hline TZMSR-W & $1.82^{\mathrm{b}}$ & $1.76^{\mathrm{bc}}$ & $1.80^{\mathrm{bc}}$ & $1.06^{\mathrm{a}}$ & $0.90^{\mathrm{abc}}$ & $0.98^{\mathrm{a}}$ & $17.25^{\mathrm{a}}$ & $13.93^{\mathrm{a}}$ & $15.59^{\mathrm{a}}$ & $15.76^{\mathrm{cd}}$ & $14.71^{\mathrm{a}}$ & $15.24^{\mathrm{a}}$ \\
\hline DMESR-Y & $1.58^{\mathrm{C}}$ & $1.55^{\mathrm{C}}$ & $1.57^{\mathrm{d}}$ & $1.06^{a}$ & $0.82^{\mathrm{bc}}$ & $0.94^{a}$ & $15.00^{b}$ & $11.38^{\mathrm{ab}}$ & $14.44^{\mathrm{ab}}$ & $15.88^{\mathrm{bcd}}$ & $13.79^{a}$ & $14.84^{\mathrm{a}}$ \\
\hline ACROSS-98 & $1.65^{\mathrm{c}}$ & $1.72^{\mathrm{bc}}$ & $1.68^{\mathrm{cd}}$ & $1.03^{\mathrm{a}}$ & $1.05^{\mathrm{ab}}$ & $1.04^{\mathrm{a}}$ & $17.01^{\mathrm{a}}$ & $11.96^{\mathrm{ab}}$ & $14.49^{\mathrm{ab}}$ & $16.17^{\mathrm{abc}}$ & $14.19^{\mathrm{a}}$ & $15.18^{\mathrm{a}}$ \\
\hline TZPBSR-W & $1.88^{\mathrm{b}}$ & $1.94^{\mathrm{ab}}$ & $1.91^{b}$ & $0.97^{\mathrm{a}}$ & $1.07^{\mathrm{a}}$ & $1.02^{a}$ & $15.79^{\mathrm{ab}}$ & $13.37^{\mathrm{a}}$ & $14.58^{\mathrm{ab}}$ & $15.61^{\mathrm{cd}}$ & $14.71^{a}$ & $15.16^{\mathrm{a}}$ \\
\hline CV (\%) & 7.98 & 11.31 & 5.11 & 7.13 & 20.25 & 13.50 & 8.73 & 17.37 & 11.02 & 4.90 & 8.24 & 5.68 \\
\hline
\end{tabular}


Table 3: Effect of variety on mean-number of rows per ear, mean number of kernels per row, mean ear-weight and Shelling percentage of maize in Jos-Plateau.

\begin{tabular}{|c|c|c|c|c|c|c|c|c|c|c|c|c|c|c|}
\hline \multirow{2}{*}{$\begin{array}{l}\text { Treatment } \\
\text { Variety } 2007\end{array}$} & \multicolumn{3}{|c|}{ No. of rows/ear } & \multicolumn{4}{|c|}{ No. of kernels/row } & \multirow[b]{2}{*}{2007} & \multicolumn{3}{|c|}{ Mean ear-weight (g) } & \multicolumn{3}{|c|}{ Shelling percentage } \\
\hline & 2008 & Pooled & & 2007 & 2008 & Pooled & & & 2008 & Pooled & 2007 & 2008 & Pooled & \\
\hline SUWAN-I-Y & $15.86^{\mathrm{ab}}$ & $13.08^{\mathrm{a}}$ & $14.47^{\mathrm{a}}$ & & $31.04^{\mathrm{bc}}$ & $18.81^{\mathrm{a}}$ & $24.93^{\mathrm{a}}$ & & $152.87^{\mathrm{a}}$ & $87.30^{\mathrm{a}}$ & $120.09^{\mathrm{a}}$ & $79.30^{\mathrm{cd}}$ & $76.44^{\mathrm{a}}$ & $77.87^{\circ}$ \\
\hline KENYA KITALI & $11.23^{\mathrm{c}}$ & $11.90^{\mathrm{a}}$ & $11.57^{c}$ & & $28.04^{c}$ & $19.38^{\mathrm{a}}$ & $23.71^{\mathrm{a}}$ & & $141.22^{\mathrm{a}}$ & $101.71^{\mathrm{a}}$ & $121.47^{\mathrm{a}}$ & $78.78^{d}$ & $64.76^{\mathrm{b}}$ & $74.27^{\circ}$ \\
\hline ACR-9776-2 & $14.67^{\mathrm{ab}}$ & $13.56^{\mathrm{a}}$ & $14.11^{\mathrm{ab}}$ & & $37.41^{\mathrm{a}}$ & $21.79^{a}$ & $29.60^{\mathrm{a}}$ & & $144.56^{\mathrm{a}}$ & $93.03^{\mathrm{a}}$ & $118.79^{a}$ & $88.77^{\mathrm{a}}$ & $78.45^{\mathrm{a}}$ & $81.11^{\mathrm{a}}$ \\
\hline TZMSR-W & $14.60^{\mathrm{b}}$ & $12.50^{\mathrm{a}}$ & $13.55^{\mathrm{ab}}$ & & $33.27^{\mathrm{ab}}$ & $21.42^{\mathrm{a}}$ & $27.34^{\mathrm{a}}$ & & $165.95^{\mathrm{a}}$ & $92.52^{\mathrm{a}}$ & $129.23^{a}$ & $81.58^{b}$ & $75.22^{\mathrm{ab}}$ & $78.41^{a}$ \\
\hline DMESR-Y & $15.97^{\mathrm{a}}$ & $12.98^{\mathrm{a}}$ & $14.47^{\mathrm{a}}$ & & $33.93^{\mathrm{ab}}$ & $18.13^{\mathrm{a}}$ & $26.03^{\mathrm{a}}$ & & $148.91^{\mathrm{a}}$ & $82.09^{a}$ & $115.50^{\mathrm{a}}$ & $79.72^{\text {bcd }}$ & $73.98^{\mathrm{ab}}$ & $76.85^{\mathrm{a}}$ \\
\hline ACROSS-98 & $14.83^{\mathrm{ab}}$ & $12.99^{\mathrm{a}}$ & $13.91^{\mathrm{ab}}$ & & $34.30^{\mathrm{ab}}$ & $18.92^{\mathrm{a}}$ & $26.61^{\mathrm{a}}$ & & $171.98^{\mathrm{a}}$ & $89.81^{\mathrm{a}}$ & $130.90^{\mathrm{a}}$ & $81.59^{b}$ & $69.02^{\mathrm{ab}}$ & $75.31^{a}$ \\
\hline TZPBSR-W & $15.15^{\mathrm{ab}}$ & $12.60^{\mathrm{a}}$ & $13.88^{\mathrm{ab}}$ & & $32.13^{b c}$ & $20.08^{a}$ & $27.11^{\mathrm{a}}$ & & $136.87^{a}$ & $112.80^{\mathrm{a}}$ & $124.84^{\mathrm{a}}$ & $81.13^{b c}$ & $77.61^{a}$ & $79.37^{\circ}$ \\
\hline CV (\%) & 6.86 & 21.82 & 9.23 & & 11.16 & 35.33 & 15.42 & & 17.26 & 36.28 & 16.39 & 2.00 & 11.72 & 6.27 \\
\hline
\end{tabular}

Table 4: Effect of variety on 1,000 seed weight, grain yield per plant and total grain yield of maize in Jos-Plateau

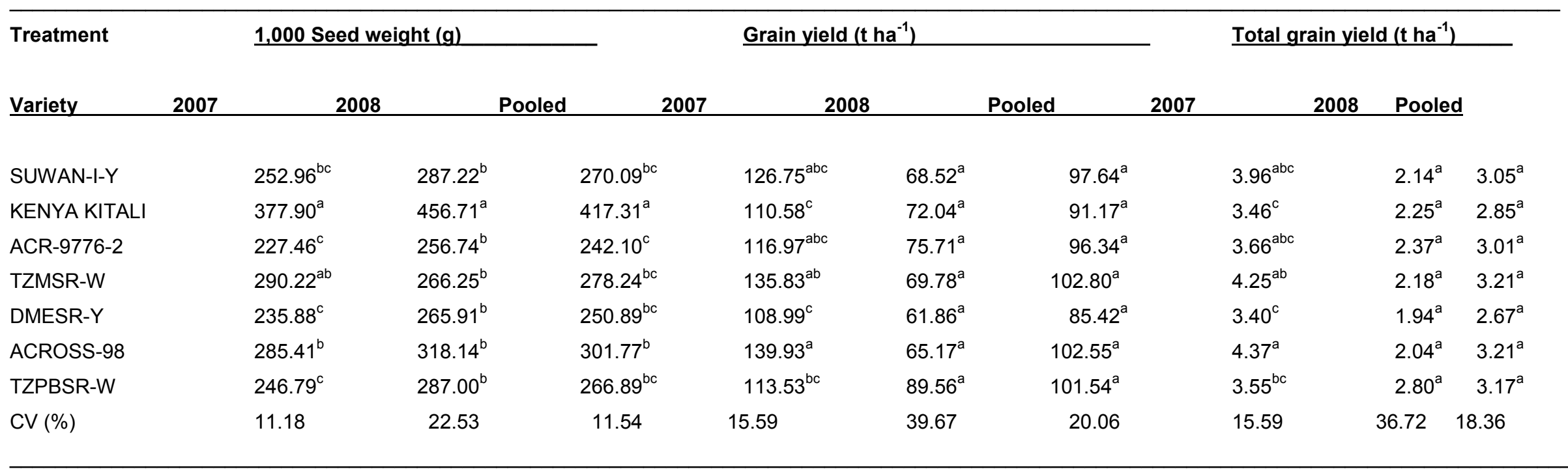




\section{DISCUSSION AND CONCLUSION}

The variety 'Kenya Kitali' took a longer time to transit from the vegetative to the reproductive phase, an indication that it is late-maturing and that tasselling and silking are influenced by the genotype and environment. Breeding for maturity is important in maize improvement. Maturity traits include the number of days from planting to flowering, brown huskformation,kernel moisture at harvest and black layer formation (Dhillon and Prassanna, 2001). Days to silk is widely used as an index to maturity. The expression of these traits differs with season and location as they are affected by environmental factors.

The mean number of ears per plant, ear-length, ear-width and the mean number of rows per ear all varied with genotype and ear. Dhillon and Prassanna (2001) have identified number of ears, kernel rows, kernels per row, seed weight and shelling percentage as the major components of total grain yield in maize.

The variation in the grain yield per plant and in the total grain yield with variety and year shows that grain yield in maize is quantitatively inherited and that it is genotypically and environmentally influenced.

\section{CONCLUSION}

The results of this study indicate that growth, yield and yield components of maize vary with genotype and environment. The varieties ACROSS-98, ACR9776-2, TZMSR-W and 'Kenya kitali' showed promising potentials for high productivity in the Jos-Plateau environment.

\section{ACKNOWLEDGEMENTS}

The authors are sincerely thankful to the Management of the Potato Programme of the National Root Crops Research Institute, Kuru, Plateau State, for providing the land for this experiment.

\section{REFERENCES}

CIMMYT., 1994. CIMMYT 1993/94 World Maize Facts and Trends. Maize Seed Industries Revisited. Emerging Roles of the Public and Private Sectors. CIMMYT, Mexico, D. F. Mexico.
Crosbie, T. M. and J. J. Mock., 1981. Changes in physiological traits associated with grain yield improvement in three maize programmes. Crop Science 21:255-259.

Dhillon, B. S. and B. M. Prassanna., 2001. Maize. In: V. L. Chopra (ed.) Breeding Field Crops: Theory and Practice. Oxford \& IBH Publishing Co., New Delhi. 147-185.

Downswell, C. R., R. L. Paliwal and R. P. Cantrell., 1996. Maize in the Third World. Westview Press, Boulder, USA.

Duvick, D. N., 1992. Genetic contributions to advances in yield of U.S. maize. Maydica. 37: 69-79.

Duvick, D. N., 1998. Crop Improvement: emerging trends in maize. In: V.L. Chopra, R.B. Singh, Anupam Varma (eds). Crop Productivity and Sustainability - Shaping the future. Proceedings of the $2^{\text {nd }}$ International Crop Science Congress. Oxford and IBH Publishing Co., New Delhi. 127-138.

Rosegrant, M. W., M. Agcaoili-Sombilla and N. D. Perez., 1995. Global Food Projectionsto 2020: Implications for Investment. Food, Agriculture and Environment Discussion Paper No 5, October 1995. International Food Policy Research Institute, Washington D.C., USA.

Russell, W. A., 1991. Genetic improvement of maize yield. Advances in Agronomy 46: 245-298.

Shaw, R. H., 1988. Climatic Requirement. In: G.F. Sprague, J. W. and Dadley (eds.) Corn and Corn Improvement. American Society of Agronomy, Madison, Wiscorisin, USA. 609638.

Steel, R. G. D. and J. H. Tome, 1960. Principles and Procedures of Statistics. McGraw-Hill Book Co. Inc., New York. 480.

USDA., 1996. Grain: World Market and Trade. United States Department of Agriculture Circular Series FG 9-96, September 1996. 